\title{
STATUS GIZI, AKTIVITAS FISIK, PERSEPSI MANFAAT, DAN HAMBATAN PEMENUHAN ASUPAN GIZI ORANG DENGAN HIVIAIDS
}

\author{
Nutritional Status, Physical Activity, and Perceived of Benefits and Barriers to Fulfilling The \\ Nutrition Intake of People Living With HIV/AIDS
}

Forman Novrindo Sidjabat ${ }^{1}$, Nining Tyas Triatmaja ${ }^{2}$, Amelia Bevi ${ }^{1}$

${ }^{1}$ Fakultas Teknologi dan Manajemen Kesehatan, Institut IImu Kesehatan Bhakti Wiyata Kediri

${ }^{2}$ Fakultas Kesehatan, Institut IImu Kesehatan Bhakti Wiyata Kediri

E-mail: sidjabat.fn@iik.ac.id

\begin{abstract}
One of the efforts to improve the quality of life of people living with HIVIAIDS (PLWHA) is to maintain optimal nutritional status so that it can increase immunity to infection and disease, increase energy and be more productive. This study aims to describe the nutritional status, physical activity, and perceived benefits and barriers to fulfilling the nutritional intake of people living with HIVIAIDS (PLWHA). This research was a descriptive study using mixed methods. Data were collected on 5 female PLWH informants using a $2 \times 24$ hour food recall to determine consumption patterns and measure nutritional status based on $B M I$ and the adequacy of nutritional intake (macro includes energy, protein, fat, carbohydrates; and micro including Vit. A, Vit. B, Vit. C, Zn); and the calculation of physical activity used the Physical Activity Level (PAL). In-depth interviews were conducted to explore perceived the benefits and barriers of PLWHA to fulfilling their nutritional needs and were analyzed using the Rapid and Rigorous Qualitative Data Analysis technique with triangulation informant. The BMI status of informants was 3 normal informants, 1 overweight informant, and 1 obese informant. Types of physical activity carried out were 4 informants doing light physical activity and 1 informant doing moderate physical activity. The frequency of eating the seams of informants is 3 times a day and the number of informants with normal adequacy of fat and energy intake is 1 informant each and 2 informants protein, carbohydrate nutrition intake is not sufficient. The adequacy of normal micronutrients is vitamin $b$ for 2 informants, vitamin $c$, and $b$ for 1 informant each. The informants know that nutrients can increase immunity, but the types of consumption by the informants have not varied. Assistance services, counseling, and nutrition education are also needed during the HIV / AIDS treatment process.
\end{abstract}

Keywords: HIVIAIDS, PLWHA, nutrition adequacy rate

\section{ABSTRAK}

Salah satu upaya meningkatkan kualitas hidup Orang dengan HIV/AIDS (ODHA) adalah mempertahankan status gizi optimal sehingga dapat meningkatkan kekebalan terhadap infeksi dan penyakit, peningkatan energi dan akan lebih produktif. Penelitian ini bertujuan untuk menggambarkan status gizi, aktivitas fisik, serta persepsi manfaat dan hambatan pemenuhan asupan gizi orang dengan HIVIAIDS (ODHA). Penelitian ini merupakan penelitian deskriptif menggunakan metode campuran. Data dikumpulkan pada 5 informan ODHA perempuan dengan menggunakan food recall $2 \times 24$ jam untuk mengetahui pola konsumsi dan mengukur status gizi berdasar pada IMT dan kecukupan asupan gizi (makro meliputi energi, protein, lemak, karbohidrat; dan mikro meliputi vitamin A, vitamin B, vitamin C, Zn); perhitungan aktivitas fisik menggunakan Physical Activity Level (PAL). Wawancara mendalam dilakukan untuk menggali persepsi manfaat dan hambatan ODHA mencukupi kebutuhan gizi dan dianalisa menggunakan teknik Rapid and Rigorous Qualitative Data Analysis dengan informan triangulasi. Status IMT informan adalah 3 informan normal, 1 informan gemuk, dan 1 informan obesitas. Jenis aktivitas fisik yang dilakukan adalah 4 informan melakukan aktivitas fisik ringan dan 1 informan melakukan aktivitas fisik sedang. Frekuensi makan keliman informan sebanyak $3 x$ sehari dan jumlah informan dengan kecukupan normal pada asupan lemak dan energi masing-masing 1 informan dan protein sebanyak 2 informan, asupan gizi karbohidrat tidak tercukupi. Kecukupan gizi mikro normal adalah vitamin B pada 2 informan, vitamin C dan B masingmasing 1 informan. Informan mengetahui zat gizi dapat meningkatkan kekebalan tubuh tapi jenis konsumsi informan belum beragam. Diperlukan juga layanan pendampingan, konseling dan edukasi gizi, selama proses pengobatan HIVIAIDS.

Kata kunci: HIVIAIDS, ODHA, angka kecukupan gizi

Doi: $10.36457 /$ gizindo.v44i1.556

www.persagi.org/ejournal/index.php/Gizi_Indon 


\section{PENDAHULUAN}

S ecara global dilaporkan sebanyak total 37,9 juta orang di dunia pada akhir tahun 2018 hidup dengan Human Immunodeficiency Virus/Acquired Immunodeficiency Syndrome (HIVIAIDS) diantaranya 36,2 juta dewasa dan 1,7 juta anak usia $<15$ tahun. ${ }^{1}$ Data insiden HIV hingga tahun 2018 dilaporkan sebanyak 1,7 juta orang dan 770.000 kematian yang berkaitan dengan HIVIAIDS. Asia tenggara 3,8 juta terbanyak kedua setelah Afrika. Di Indonesia kasus HIV kumulatif hingga 2019 mencapai total 377.564 (50.282 tahun 2019 meningkat dari tahun 2018 sebanyak 46.659) orang dan 121.101 (7.036 tahun 2019 menurun dari 10.190 ditahun 2018) orang dengan AIDS Sementara angka kematian akibat HIVIAIDS kumulatif dari 1 April 1987 hingga 2019, diketahui bahwa ada 17.087 kematian kumulatif dengan 614 kematian di tahun 2019.2 Provinsi Jawa Timur merupakan salah satu dari lima Provinsi dengan kasus kejadian HIV tertinggi sebanyak 8.935 (kumulatif 57.176), AIDS sebanyak 958 orang (kumulatif 20.787) dengan kumlatif kematian akibat AIDS sebanyak 4.412 orang selain DKI Jakarta, Jawa Barat, Jawa Tengah dan Papua. ${ }^{2}$ Kota Kediri merupakan salah satu dari 5 besar kota dengan proporsi HIVIAIDS yang tinggi berdasarkan kelompok umur di provinsi Jawa Timur yaitu sebesar 17 persen pada tahun 2015. Pada akhir 2018 tercatat ada 1.300 ODHA di Kota Kediri dan kasus baru ditahun 2018 sebanyak sekitar 200 kasus dengan 60 persen jenis kelamin laki-laki. ${ }^{3}$

Program pengendalian HIVIAIDS tidak hanya berfokus pada pencegahan munculnya infeksi baru, tapi mencegah kematian akibat AIDS melalui program 909090 (triple ninety). ${ }^{4}$ Mengendalikan dan mencegah munculnya infeksi penyerta merupakan cara mencegah mingkatnya angka kematian pada ODHA. Upaya mencegah kematian yang sekaligus meningkatkan kualitas hidup Orang dengan HIVIAIDS (ODHA) salah satunya dengan program dukungan asupan gizi. ${ }^{5}$ Gizi yang baik dapat meningkatkan kekebalan terhadap infeksi dan penyakit, peningkatan energi dan akan lebih produktif. Seseorang dengan infeksi HIV lebih berisiko mengalami gangguan gizi karena berkurangnya asupan makanan, penyerapan yang buruk, perubahan metabolisme, munculnya infeksi penyerta dan penyakit kronis, anoreksia, diare, demam, mual, infeksi mulut dan esofagus, anemia, dan kurangnya aktivitas fisik. ${ }^{5-7}$ Hasil penelitian lain pada ODHA yang mengikuti program suplementasi makanan pada saat proses pengobatan melaporkan peningkatan kepatuhan pengobatan, berkurangnya efek samping, peningkatan nafsu makan, peningkatan berat badan, pemulihan kekuatan fisik, dan dimulainya kembali aktivitas persalinan. ${ }^{8}$ Pemberian gizi yang adekuat dan konsumsi air bersih yang aman akan meningkatkan efektifitas untuk mencegah keparahan dan munculnya infeksi penyerta baru. ${ }^{9,10}$ Di daerah dengan seroprevalensi HIV tinggi, ODHA yang memiliki infeksi penyerta akan meningkatkan morbiditas dan mortalitas serta berdampak pada pembiayaan pengobatan dan kebutuhan pangan secara bersamaan. ${ }^{11-13}$.

Seorang ODHA, baik yang menjalankan terapi antiretroviral (ARV) maupun tidak selain perlu mempertahankan status gizi dan asupan gizi adekuat, perlu juga meningkatkan aktivitas fisik. Aktivitas fisik berperan untuk meningkatkan imunitas, mencegah dari penyakit kronis lain, mencegah lipodistrofi yang menyebabkan resistensi insulin, dislipidemia dan penyakit kardiovaskular. ${ }^{14,15}$ Penelitian lain menemukan efek aktivitas fisik pada 60 persen ODHA yang memiliki kelainan metabolik adalah perbaikan komposisi tubuh dengan lingkar pinggang dan rasio pinggang-pinggul yang menurun dan peningkatan massa tubuh tanpa lemak, serta kebugaran kardiometabolik pada semua faktor risiko penyakit kardiovaskular. ${ }^{16}$ Pada mereka yang melakukan terapi ARV juga didapatkan prevalensi kelebihan berat badan dan obesitas yang lebih tinggi. Obesitas bisa berdampak negatif terhadap fungsi kekebalan tubuh. ${ }^{17-20}$ Dari penelitian yang dilakukan di rumah sakit pendidikan di Yogyakarta pada ODHA yang menjalankan terapi ARV didapatkan 72,72 persen mengalami peningkatan berat badan pada enam bulan pertama dengan 41 persen diantaranya mengalami peningkatan berat badan 10 persen dari berat badan sebelumnya dan didapatkan 16,67 persen pasien mengalami penurunan berat badan karena adanya infeksi lain yaitu radang tenggorokan, flu, batuk, hepatitis, Tuberkulosis, dan kandidiasis. ${ }^{21}$ Bahkan sebagian sudah masuk dalam kategori wasting syndrome, yaitu suatu keadaan di mana pasien 
kehilangan berat badan $>10$ persen atau mempunyai indeks massa tubuh $<20 \mathrm{~kg} / \mathrm{m} 2$ sejak kunjungan terakhir atau kehilangan berat badan $>5$ persen dalam waktu enam bulan dan kondisi ini bertahan selama satu tahun. ${ }^{22}$

ODHA perlu sekitar 10-15 persen lebih banyak kalori dibandingkan kelompok tanpa HIV (400 kalori tambahan untuk laki-laki dan 300 kalori untuk perempuan). Pada kondisi tanpa HIV seseorang biasanya membutuhkan 57 gram protein untuk laki-laki dan 48 gram untuk perempuan, namun bagi ODHA kebutuhan akan bertambah sekitar 50-100 persen atau 85 gram protein untuk laki-laki dan 72 gram untuk perempuan. ${ }^{23}$ Asupan vitamin dibutuhkan untuk mengatur berbagai proses metabolisme dalam tubuh, mempertahankan fungsi berbagai jaringan serta mempengaruhi dalam pembentukan sel-sel baru, serta asupan mineral yang digunakan untuk proses metabolisme tubuh. ${ }^{24}$ Kebutuhan karbohidrat berdasarkan proporsi energi dari karbohidrat adalah 60-75 persen dari total energi, kebutuhan lemak berdasarkan proporsi energi dari lemak yaitu berkisar 20-25 persen dari total energi.6,25 Maka dari itu ODHA perlu menjaga serta memenuhi asupan gizi dan aktivitas fisik untuk meningkatkan kualitas hidup dan kesehatan fisiknya. Penelitian ini bertujuan untuk mengetahui gambaran status gizi, aktivitas fisik, serta persepsi manfaat dan hambatan pemenuhan asupan gizi orang dengan HIVIAIDS (ODHA).

\section{METODE}

Penelitian ini merupakan penelitian deskriptif menggunakan metode campuran (kuantitatif dan kualitatif) yang dilakukan pada Mei 2019 di Lembaga Setulus Kasih Kota Kediri. Dilakukan pada 5 ODHA berjenis kelamin perempuan yang didapatkan menggunakan teknik snowball sampling sebagai informan utama. Studi kuantitatif meliputi pengukuran antropometri untuk memnentukan status gizi berdasarkan indeks massa tubuh, food recall $2 \times 24$ jam untuk menilai pola konsumsi dan asupan makan (gizi mikro meliputi Vit.A, Vit.B, Vit.C, Zn dan makro meliputi Energi, Protein, Lemak, Karbohidrat) dan Physical Activity Level (PAL) untuk mengukur aktivitas fisik. Studi kualitatif dilakukan untuk menggali persepsi manfaat dan hambatan ODHA untuk mencukupi kebutuhan gizi menggunakan indepth interview. Pengumpulan data dilakukan oleh peneliti dan seorang enumerator yang sudah dilatih melakukan pengukuran antropometri menggunakan timbangan manual HL 3051 dan microtoise GEA 2 meter.

Analisis data kuantitatif yang dilakukan secara univariat untuk melihat pola konsumsi individu dapat dilihat dari frekuensi makan dalam 1 hari dan tingkat konsumsi individu yang didapatkan dari hasil perhitungan kandungan zat gizi yang dikonsumsi, perhitungan zat gizi yang di makan diperoleh dari penjumlahan konsumsi zat gizi hari pertama dan hari kedua kemudian dibagi 2. Penilaian status gizi pada usia dewasa dapat dilakukan dengan mengukur IMT (Indeks Masaa Tubuh) dengan rumus: $\mathrm{BB} / \mathrm{TB}^{2}$, hasil dari perhitungan digolongkan menurut hasil IMT akhir dengan kategori $<17,0$ sangat kurus , 17,0-18,4 kurus, 18,5-25,0 normal, 25,1-27,0 gemuk, dan $>27,0$ obesitas. ${ }^{26}$ Penilaian status gizi juga dilakukan dengan mengukur kebutuhan gizi dan asupan gizi yang kemudian dibandingkan dengan angka kecukupan gizi masing-masing parameter gizi makro (energi, protein, lemak, dan karbohidrat), dan gizi mikro (vitamin a, vitamin b, vitamin $\mathrm{c}$, dan Zink). Kemudian untuk gizi makro dikategorikan menjadi defisit berat jika $<70$ persen AKG. defisit sedang jika 70-79 persen AKG, defisit ringan jika 80-89 persen AKG, normal jika 90-100 persen AKG, dan lebih jika $\geq$ 110 persen AKG. Gizi mikro dikategorikan menjadi kurang jika $\leq 77$ persen AKG dan normal jika $\geq 77$ persen AKG. ${ }^{27}$ Aktivitas fisik dihitung berdasarkan jenis dan waktu aktivitas, kemudian dikategorikan menjadi Ringan : 1,401,69, Sedang : 1,70-1,99 dan Berat : 2,00-2,40.

Analisis data kualitatif akan menggunakan teknik RADaR (Rapid and Rigorous Qualitative Data Analysis) berdasarkan pendekatan individual dan kelompok untuk melakukan coding dan analisis data. ${ }^{28}$ Adapun langkah dalam teknik RADaR ini antara lain (1) Memastikan semua data ditranskrip dalam format yang sama dan terstandard, (2) Menempatkan data transkrip yang sudah terformat ke dalam tabel data fase 1, (3) Mereduksi data pada fase 1 untuk memproduksi data fase 2 dalam tabel, (4) Mereduksi data fase 2, dan (5) Draft luaran studi menggunakan data fase final. Untuk keabsahan data kualitatif 
yang didapatkan, penelitian ini menggunakan triangulasi sumber yaitu Sekretaris Komisi Perlindungan HIVIAIDS (KPAD). Penelitian ini telah melalui kaji etik Pusat Penelitian dan Pengabdian Masyarakat Institut IImu Kesehatan Bhakti Wiyata Kediri dengan nomor 440/PP2MKE/IV/2019.

\section{HASIL}

\section{Karakteristik Informan}

Informan utama berjumlah 5 orang perempuan dengan usia 26-35 tahun 2 orang, 36-45 tahun 2 orang dan 46-55 tahun 1 orang. Dan status pekerjaan informan yaitu ibu rumah tangga 1 orang, pekerja LSM 2 orang, buruh musiman 1 orang dan guru 1 orang (Tabel 1 ).

\section{Status Gizi dan Aktivitas Fisik}

Dari hasil pengukuran IMT pada kelima informan terbagi berdasarkan kategori IMT menjadi 60 persen normal, 20 persen gemuk, dan 20 persen obesitas, berdasarkan jenis aktivitas fisik 80 persen informan melakukan aktivitas fisik ringan seperti melakukan pekerjaan rumah tangga sehari-hari (menyapu, memasak, mencuci, menjemur dan menyertika pakaian), bekerja (menjaga toko dan menjajar) dan 20 persen informan melakukan aktivitas fisik sedang seperti aerobik selain bekerja dan melakukan pekerjaan rumah tangga (Gambar 1).

Tabel 1

Karakteristik Informan

\begin{tabular}{lc}
\hline Karakteristik & Frekuensi $(\mathrm{n}=5)$ \\
\hline Usia & 2 \\
a. $26-35$ tahun & 2 \\
b. $36-45$ tahun & 1 \\
c. $46-55$ tahun & \\
Pekerjaan & 1 \\
a. Ibu rumah tangga & 2 \\
b. Pekerja LSM & 1 \\
c. Buruh musiman & 1 \\
d. Guru & \\
\hline
\end{tabular}
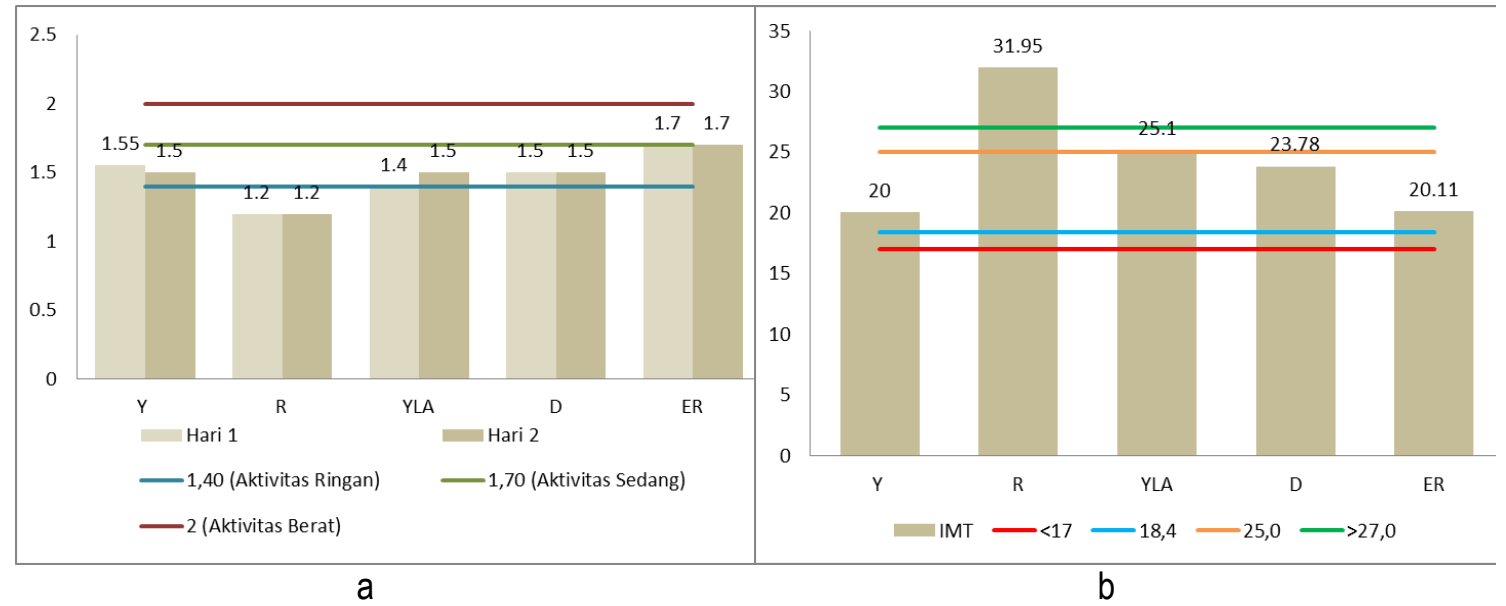

Gambar 1

Nilai (a) Aktivitas Fisik dan (b) Indeks Massa Tubuh (IMT) 
Pola Konsumsi dan Kecukupan Gizi

Pola konsumsi individu dapat dilihat dari frekuensi makan dalam 1 hari dan tingkat konsumsi individu yang didapatkan dari hasil perhitungan food recall $2 \times 24$ jam.

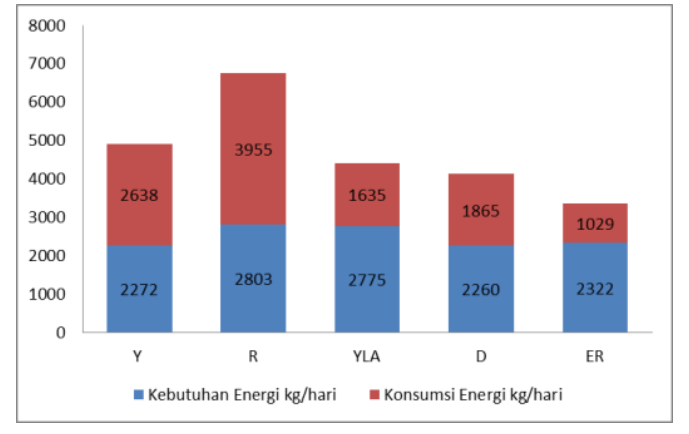

a

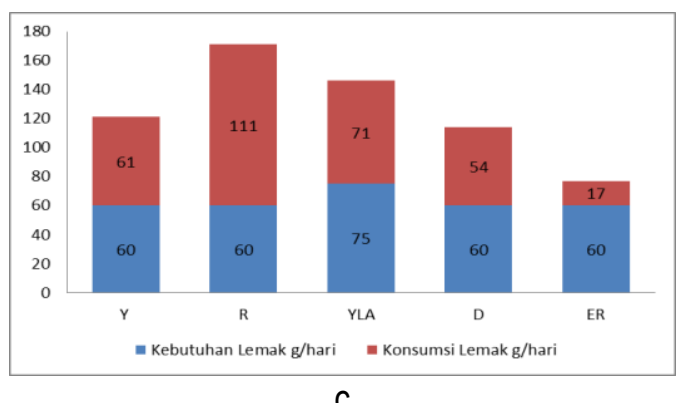

C

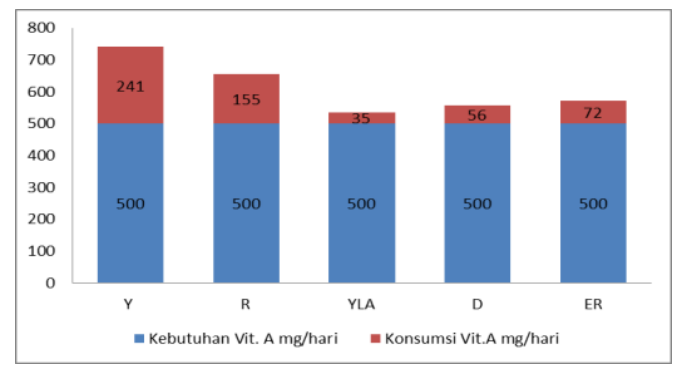

e

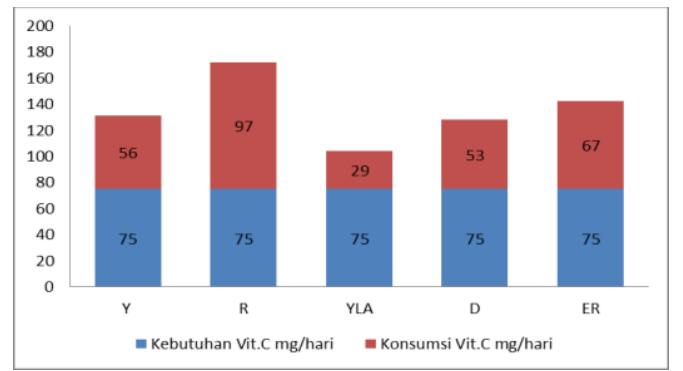

g

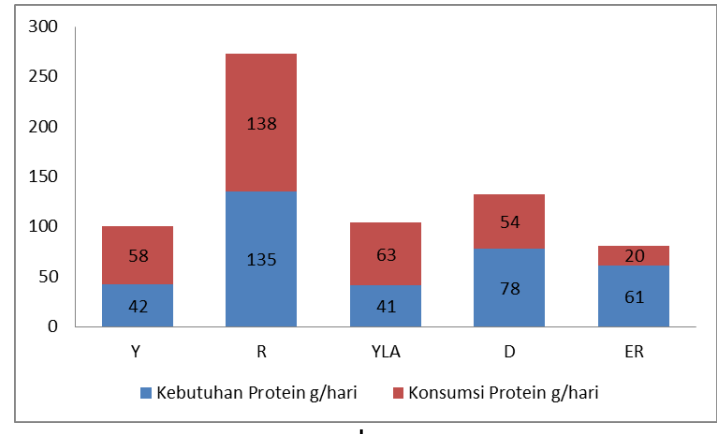

b
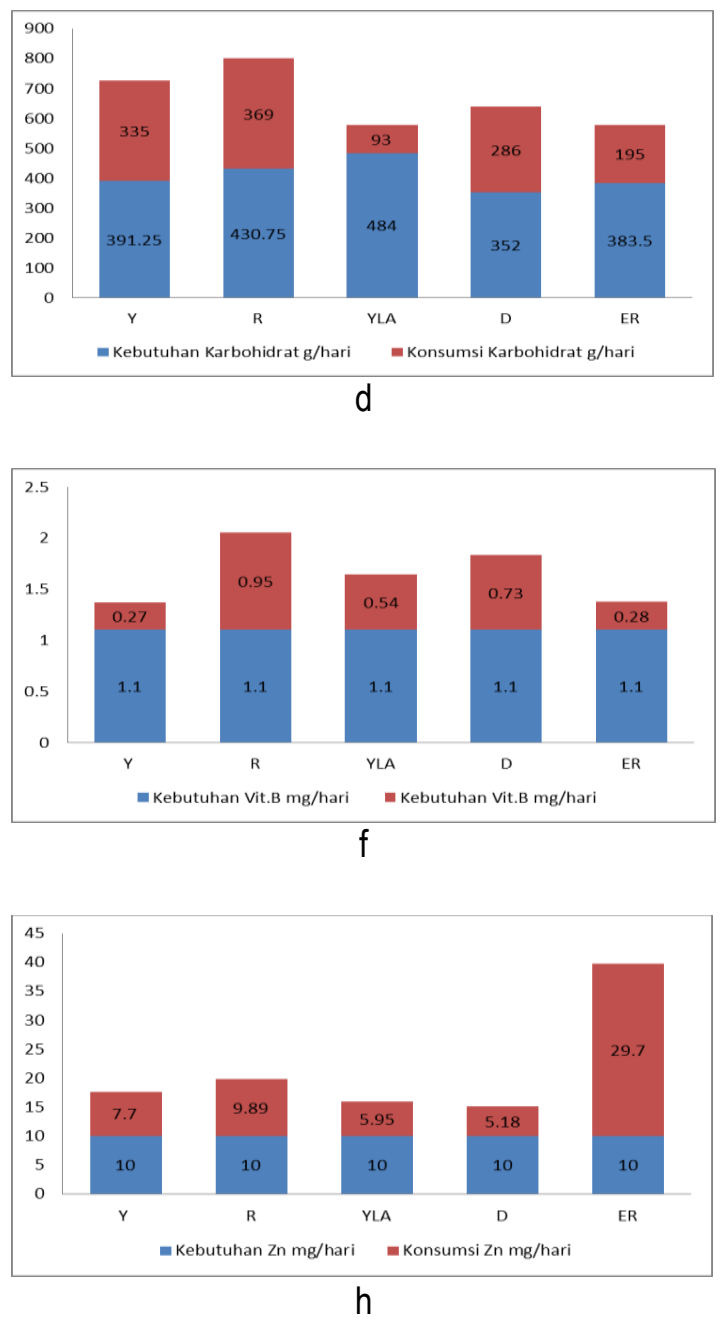

Gambar 2

Asupan (a) Energi, (b) Protein, (c) Lemak, (d) Karbohidrat, (e) Vitamin A, (f) Vitamin B, (g) Vitamin C, dan (h) Zink 
Untuk perbandingan kebutuhan dengan asupan gizi (Gambar 2) dan angka kecukupan gizi (Gambar 3) masing-masing informan hasilnya adalah, informan 1 (Y) memiliki kecukupan energi dan protein normal, kecukupan lemak dan karbohidrat defisit ringan dan kecukupan vitamin $A, B, C$ kurang dan $\mathrm{Zn}$ normal. Informan 2 (R) memiliki kecukupan energi, lemak lebih,kecukupan protein, vitamin $\mathrm{B}, \mathrm{C}$ dan $\mathrm{Zn}$ normal dan kecukupan karbohidrat defisit ringan. Informan 3 (YLA) memiliki kecukupan energi, karbohidrat defisit berat, kecukupan protein lebih, dan tingkat kecukupan lemaknormal, dan kecukupan vitamin $A, B, C$ dan Zn kurang. Informan 4 (D) memiliki kecukupan energi, lemak, karbohidrat defisit ringan, kecukupan protein defisit berat dan kecukupan vitamin $A, B, C$, dan Zn kurang. Informan 5 (ER) memiliki kecukupan energi, protein, karbohidrat, yang dikonsumsi oleh informan defisit berat, dan kecukupan vitamin $A, B, C$ kurang, dan $Z n$ Normal.

\section{Status Gizi berdasarkan Kecukupan Gizi dan Aktivitas Fisik}

Berdasarkan status gizi informan dikelompokkan menjadi tiga yaitu kelompok status gizi normal, gemuk dan obesitas. Informan yang memiliki status gizi normal adalah $Y, D$ dan ER. Informan $Y$ mengalami kekurangan asupan vitamin $A$, vitamin $B$, dan vitamin $C$; asupan energi dan protein normal dan asupan lemak dan karbohidrat defisit ringan dengan aktivitas fisik ringan. Informan $D$ mengalami kekurangan vitamin $A$, vitamin $B$, vitamin $C$, dan Zink; asupan energi, protein dan karbohidrat mengalami defisit ringan; dan asupan lemak defisit berat dengan aktivitas fisik ringan. Informan ER mengalami kekurangan asupan vitaim $A$, vitamin $B$, vitamin $C$, defisit berat gizi makro dan asupan Zink normal dengan aktivitas fisik sedang.

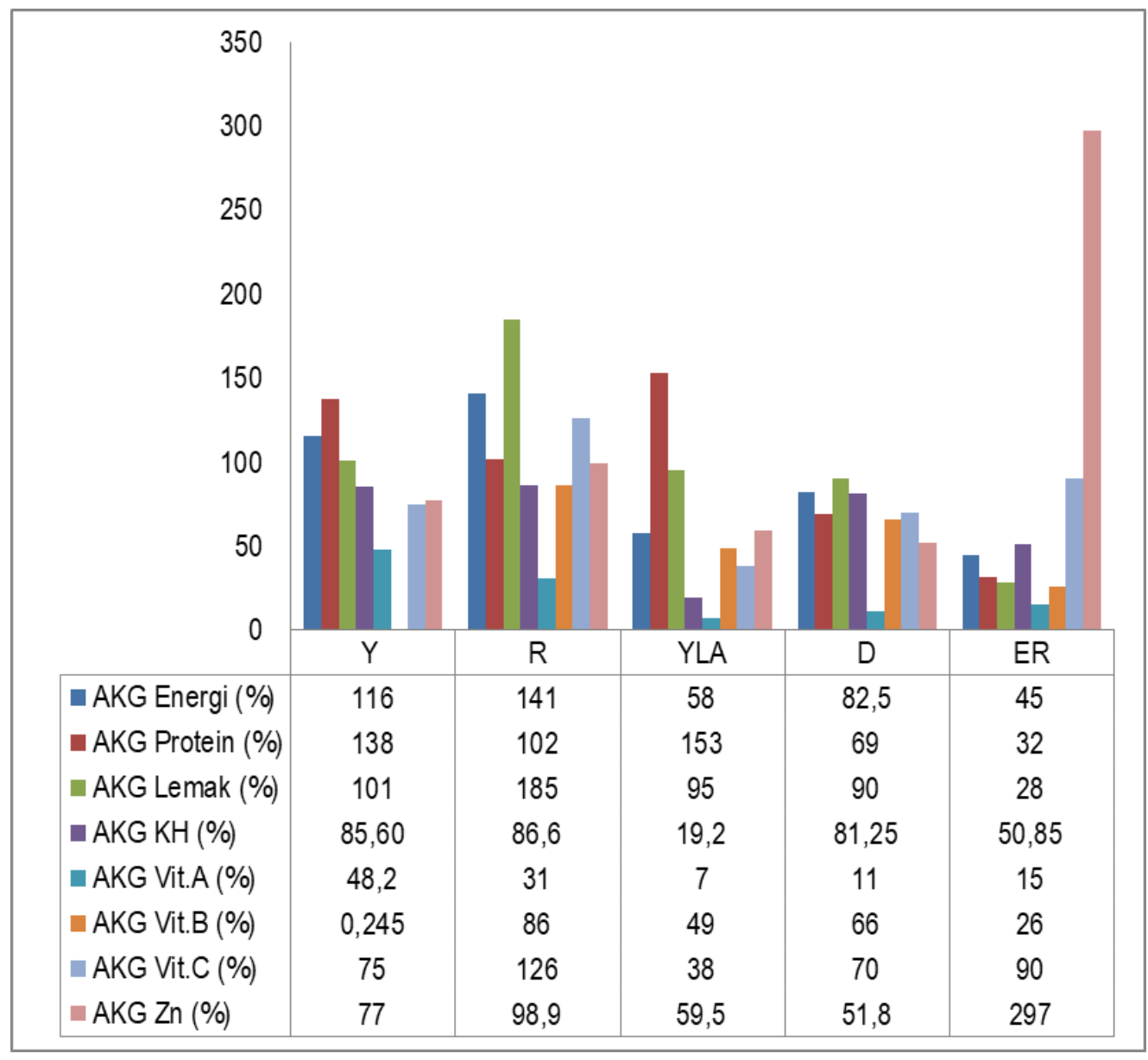

Gambar 3

Angka Kecukupan Gizi ( persen) 
Tabel 2

Reduksi Hasil Pengukuran Usia, Status Gizi, Aktivitas Fisik, Frekuensi Makan, dan Kecukupan Gizi (Makro dan Mikro)

\begin{tabular}{|c|c|c|c|c|c|c|c|c|c|c|c|}
\hline \multirow[b]{2}{*}{ Nama } & \multirow[b]{2}{*}{ Usia } & \multirow{2}{*}{$\begin{array}{l}\text { Status } \\
\text { Gizi }\end{array}$} & \multirow{2}{*}{$\begin{array}{c}\text { Aktivitas } \\
\text { Fisik }\end{array}$} & \multirow{2}{*}{$\begin{array}{c}\text { Frekuensi } \\
\text { Makan }\end{array}$} & \multicolumn{7}{|c|}{ Kecukupan Gizi Makro dan Mikro } \\
\hline & & & & & Energi & Protein & Lemak & $\begin{array}{l}\text { Karbo } \\
\text { hidrat }\end{array}$ & $\begin{array}{c}\text { Vit. } \\
\text { A }\end{array}$ & $\begin{array}{c}\text { Vit. } \\
\text { B }\end{array}$ & $\begin{array}{l}\text { Vit. } \\
\text { C }\end{array}$ \\
\hline $\mathrm{Y}$ & 37 & Normal & Ringan & $3 x$ sehari & $\mathrm{N}$ & $\mathrm{N}$ & DR & DR & $\mathrm{K}$ & $\mathrm{K}$ & $\mathrm{K}$ \\
\hline $\mathrm{R}$ & 48 & Obesitas & Ringan & $3 x$ sehari & $L$ & $\mathrm{~N}$ & L & DR & K & $\mathrm{N}$ & $\mathrm{N}$ \\
\hline YLA & 27 & Gemuk & Ringan & $3 x$ sehari & DB & $\mathrm{L}$ & $\mathrm{N}$ & DB & K & $\mathrm{K}$ & K \\
\hline$D$ & 40 & Normal & Ring & $3 x$ & DR & $\mathrm{DB}$ & $\mathrm{DR}$ & DR & $\mathrm{K}$ & $\mathrm{K}$ & K \\
\hline ER & 42 & Normal & Sedang & $3 x$ sehari & DB & DB & DB & DB & K & $\mathrm{K}$ & K \\
\hline
\end{tabular}

Informan YLA memiliki status gizi gemuk memiliki asupan energi defisit berat, protein lebih, lemak normal, karbohidrat defisit berat dan asupan vitamin $A, B, C$ dan $Z n$ kurang, dengan aktivitas fisik ringan. Informan $R$ memiliki status gizi obesitas memiliki asupan energi dan lemak lebih; asupan protein, vitamin B, dan Zn normal; asupan karbohidrat defisit ringan dan vitamin $\mathrm{A}$ kurang, dengan aktivitas fisik ringan (Tabel 2).

\section{Persepsi Manfaat, Cara Pemenuhan dan Hambatan Pemenuhan Asupan Gizi Persepsi Manfaat dan Cara Pemenuhan Asupan Gizi}

Dari hasil wawancara manfaat gizi bagi informan adalah sebagai peningkatan kekebalan tubuh. Jenis makanan yang menjadi sumber asupan gizi masing-masing informan adalah informan 1 (Y) mengkonsumsi karbohidrat yang diperoleh dari nasi, protein dari ayam, dan vitamin dari sayuran (capjay) dan buah. Informan 2 (R) memiliki asupan lemak lebih karena banyak mengkonsumsi gorengan. Informan 3 (YLA) lebih banyak mengkonsumsi sayur dan tahu tempe. Informan 4 (D) mengkonsumsi karbohidrat dari nasi, vitamin dari sayur-sayuran. Informan 5 (ER) hanya mengkonsumsi makanan pokok.

"kalau gizi itu untuk meningkatkan kekebalan tubuh kita jadi kita perlu makanan yang bergizi" ( $\mathrm{Y}, 35$ tahun, Informan Utama) "untuk menambah kekebalan tubuh nggak drop, agar sehat."

(D, 40 tahun, Informan Utama)

“...pagi nasi 2 centong, ayam 1 potong....siang nasi 2 centong sayur capjay 2 centong buah apel dan jeruk...malam nasi 2 centong ayam sambal goreng..."

( $\mathrm{Y}, 37$ tahun, Informan Utama)

“...nasi 3 centong ayam goreng 2 potong tahu

isi....siang nasi 2 centong sambel terong kulak...malam nasi 2 centong ayam goreng 1 potong pisang goreng, rengginang...."

( $R$, 48 tahun, Informan Utama)

“....sayur, bayam, kacang, panjang, tempe, tahu....saya sedang mengurangi camilan, jadi saya jarang sekali nyamil".

(YLA, 27 tahun, Informan Utama)

"...pagi nasi 2 centong, tumis kangkung, uwi...siang nasi 2 centong sayur sop..."

(D, 40 tahun, Informan Utama)

"...saya hanya makan makanan pokok saja karena kita menhindari camilan untuk menjaga stamina dan kondisi tubuh..." (ER, 42 tahun, Informan Utama)

Setiap informan memiliki cara masingmasing untuk memperbaiki nafsu makan, guna meningkatkan gizi didalam tubuh, diantaranya adalah dengan menggunakan jamu temulawak. 
"kita minum vitamin, kalau nggak temulawak itu buat nafsu makan biar banyak makannya." (Y, 35 tahun, Informan Utama)

"yaa caranya gini saya minum jamu ramuan temulawak direbus sehari satu kali minumnya satu gelas"

( $R$, 48 tahun, Informan Utama)

Selain mengusahakan secara pribadi untuk meningkatkan asupan gizi, informan mendapatkan paket sembako dan tambahan makanan dari Pemerintah melalui upaya yang dilakukan Komisi Penanggulangan AIDS Kota Kediri. Pemberian makanan tambahan diberikan rutin oleh KPAD kepada KDS Setulus Kasih berupa sembako dan susu yang dibagikan secara rutin setiap bulan.

"ada dan itu selalu rutin seperti sembako, dan lain-lain (makanan tambahan) selalu rutin"

(ER, 42 tahun, Informan Utama)

"kalau untuk penambahan eee tambahan makanan dan gizi itu memang ada langsung dihendel oleh KPAD, tahun 2015 eee itu dihendel (ditangani) oleh KPAD jadi kita berikan susu, sembako kalau dlu kita berikan susu itu sebagai bentuk untuk penambahan nutrisi (gizi) mereka, terutama untuk warga yang menengah kebawah, untuk 2016 dan insya Allah 2017 ini tetep ini KPAD tetapi ini kita kasih ke Dinas Sosial, tapi atas rekomendasi dari KPAD." ( $\mathrm{H}$, Informan Triangulasi)

\section{Persepsi Hambatan Pemenuhan Asupan Gizi}

Walaupun informan menyadari gizi dapat meningkatkan kekebalan tubuh, namun informan tidak pernah mendapatkan edukasi gizi, pemantauan dan pendampingan gizi sehingga tidak mengetahui kebutuhan asupan gizi mereka. Informan juga mengaku tidak memahami makanan apa saja yang perlu mereka konsumsi untuk memenuhi asupan gizi sesuai kebutuhan masing-masing. Tidak ada kegiatan layanan konseling gizi untuk kebutuhan ODHA yang diselenggarakan sebagai program penanggulangan HIVIAIDS.

"belum pernah (ada kegiatan penyuluhan gizi), paling kalau pertemuan begitu cuman pas tes CD4 dan bagi obat jadi makan kayak biasa aja 4 sehat 5 semupurna ae"
( $\mathrm{Y}, 35$ tahun, Informan Utama)

"kalau selama ini saya belum ada pantauan dari ahli gizi, jadi saya secara pribadi mencari tau sendiri tentang gizi tersebut bagi ODHA tersebut."

(YLA, 27 tahun, Informan Utama)

"kayake (kayaknya) gak pernah ada mbak, aku gak pernah ikut kuwi (itu), tapi gak tau kalau pas aku gak ikut ya mbak" (ER, 42 tahun, Informan Utama)

"ya ee selama ini kalau penyuluhan kita mengenai gizi tidak ada, memang kita nanti rencananya eee bagaimana KPAD juga menambahi terkait dengan apa itu orang yang berkapasitas terkait dengan gizi, nanti kita tambah untuk di tim KPAD" $(\mathrm{H}$, Informan Triangulasi)

"yaa kalau di KPAD memang tidak ada pendampingan gizinya yang ada hanya sebuah pendampingan terkait dengan dia berobat, terus melakukan tes CD4nya terus pendampingan secara psikologis dan pelatihan seperti itu kalau di KPAD"

$(\mathrm{H}$, Informan Triangulasi)

Pada proses pemenuhan kebutuhan asupan gizi, informan tidak mempersiapkan makanan khusus untuk meningkatkan kondisi tubuh. Informan hanya mengkonsumsi makanan seadanya tanpa memikirkan kombinasi makanan guna upaya peningkatan asupan gizi khusus kondisi ODHA. Kondisi perekonomian menjadi alasan informan tidak menyiapkan makanan penunjang jika tidak mendapatkan bantuan, informan lebih mengutamakan alokasi dana untuk kebutuhan sandang lainnya.

"kalau makanan, yang ada aja mbak, gak diaturatur soalnya gak ngerti ternyata harus sesuai kebutuhan ya, dan beda-beda toh tak (saya) pikir yang penting ada sayur sama lauke (lauknya). Jadi makan apa yang ada, adanya tempe ya makan, tapi kalau disuruh beli yang macem-macem kayak susu tiap hari, makan buah tiap hari susah juga mbak. Pemasukan ya sedikit, piye (bagaimana)?" (D, 40 tahun, Informan Utama) 
"makan yang ada mbak, kayak orang biasa juga. Gak ngerti aku kalau ada aturannya, wong (soalnya) bukan orang kesehatan. Tapi untung aja dapat bantuan, kalau gak dapat ya gitu aja makannya mau beli apa-apa (makanan tambahan) mending buat anak atau bayar listrik mbak duite" (R, 48 tahun, Informan Utama)

\section{BAHASAN}

Status gizi ODHA dapat dipengaruhi oleh terapi antiretroviral (ARV) yang dijalankan. ${ }^{29}$ ARV berfungsi untuk meningkatkan imunitas karena target utama HIV adalah sel limsofit CD4 yang mengatur mekanisme kekebalan tubuh. ${ }^{30}$ Penelitian sebelumnya menyebutkan ada hubungan tingkat albumin rendah, IMT dan jumlah CD4 $<200 \mathrm{sel} / \mathrm{mm} .{ }^{31,32}$ Serum albumin yang lebih rendah dapat mengindikasikan status gizi buruk atau kondisi kesehatan lainnya dan merupakan prediktor independen mortalitas pada perempuan terinfeksi HIV. ${ }^{33}$ Apabila CD4 rendah maka ODHA cenderung mengalami penurunan berat badan dan peningkatan virologi sehingga berisiko munculnya infeksi penyerta lain. ${ }^{31,32}$ Saat menjalankan pengobatan salah satu efek samping dari ARV adalah kehilangan nafsu makan dan mengurangi konsumsi maknanan. ${ }^{34}$ Selain penurunan berat badan, terapi ARV dapat menyebabkan peningkatan berat badan. Beberapa penelitian menemukan obesitas sebagai masalah pada ODHA perempuan dibandingkan laki-laki baik di lingkungan miskin sumber daya dan kaya sumber daya. 35,36 Kenaikan indeks massa tubuh atau obesitas berkaitan dengan disfungsi jaringan adiposa, peningkatkan resistensi insulin, kelainan lipid hingga berkembangnya penyakit kardiovaskular yang tidak terkait AIDS seperti kanker dan diabetes tipe $2 .{ }^{37}$ Pada orang dengan jumlah CD4 rendah akan mengalami peningkatan berat badan yang besar setelah memulai pengobatan, sebuah studi meta-analisis menunjukkan, kenaikan berat badan merupakan efek kembalinya status kesehatan. Di Afrika, dibanding kelompok laki-laki, kelompok perempuan ODHA yang mengikuti pengobatan berbasis dolutegravir akan mengalami penambahan berat badan yang lebih besar dibandingkan dengan pengobatan berbasis efavirenz, dan penambahan semakin banyak terjadi jika dikombinasikan dengan tenofovir alafenamide (TAF).20,38

Berdasarkan hasil penelitian menunjukkan bahwa 5 informan memiliki frekuensi makan 3 kali sehari. ODHA perlu makan dengan porsi kecil tetapi sering sehingga terjadi penyerapan gizi dengan baik. Hal tersebut berguna untuk mempertahankan status gizi yang baik, membangun sistem kekebalan tubuh dan memungkinkan tubuh untuk melawan infeksi. ${ }^{6}$ Walau demikian, jenis makanan dan kandungan gizi yang dikonsumsi perlu diperhatikan untuk mencegah permasalahan gizi lain seperti obesitas maupun kegemukan. Kebiasaan mengkonsumsi makanan yang mengandung lemak dan karbohidrat akan meningkatkan risiko obesitas dan kegemukan pada ODHA. ${ }^{39}$ Pada penelitian ini ditemukan mereka yang memiliki status gizi gemuk dan obesitas mengkonsumsi makanan tinggi lemak dan karbohidrat serta sebelumnya memiliki kebiasaan mengkonsumsi camilan.

Dari hasil penelitian menunjukkan bahwa informan yang memiliki status gizi normal melakukan aktivitas fisik ringan dan sedang, informan yang memiliki status gizi gemuk dan obesitas memelakukan aktivitas fisik ringan. Dari hasil wawancara dengan informan yang memiliki aktivitas fisik ringan, waktu aktivitas banyak digunakan untuk duduk dan berdiri dengan sedikit memindah badannya seperti saat nonton tv dan tidak pernah melakukan olahraga secara rutin. Dan hasil wawancara pada informan yang mempunyai aktivitas fisik sedang yaitu informan rutin melakukan senam aerobik. Kurangnya aktifitas fisik mengakibatkan gangguan terhadap metabolisme tubuh. Beragam penyakit yang muncul akibat kurangnya aktifitas fisik berawal dari ketidakseimbangan antara energi yang masuk melalui makanan dengan energi yang dikeluarkan melalui aktivitas fisik. Kelebihan energi di dalam tubuh akan disimpan dalam bentuk lemak pada tempat-tempat penyimpanan seperti di bawah kulit atau pada bagian organ-organ tubuh lainnya..$^{40}$

Aktivitas fisik telah terbukti membantu dalam manajemen berat badan, pengembangan otot tanpa lemak, pengurangan lemak tubuh, peningkatan kekebalan, dan menunda immunosenescense terkait usia dan mengurangi peradangan kronis $^{16}$. Pada ODHA meningkatkan aktivitas fisik selain 
meningkatkan kekebalan tubuh dapat memperbaiki komposisi tubuh, kebugaran kardiometabolik, mengendalikan infeksi, mengurangi kadar glukosa dan risiko penyakit lain. ${ }^{14,15,41}$ ODHA perlu menentukan keefektifan dan keamanan aktivitas fisik untuk memastikan manfaatnya lebih besar daripada resikonya, memang belum ada efek negatif dari kelebihan aktivitas fisik pada mekanisme imunitas ODHA, namun seperti pada orang tanpa HIV kelebihan aktivitas fisik akan menimbulkan gangguan pada otot, fungsi paru dan jantung. ${ }^{14,16,41}$

Melakukan aktivitas fisik memerlukan energi diluar tubuh untuk metabolisme basal dan bergerak, sedangkan paru-paru memerlukan tambahan energi untuk mengantarkan zat-zat gizi. Orang gemuk menggunakan lebih banyak energi untuk melakukan suat pekerjaan dari pada orang kurus, karena orang gemuk membutuhkan usaha lebih besar untuk menggerakkan badan. ${ }^{26}$ Pada informan yang memiliki status gizi obesitas yaitu disebabkan oleh aktivitas fisik yang kurang dengan asupan makanan yang lebih sehingga masukan dan pengeluaran tidak seimbang. Obesitas pada ODHA dapat menyebabkan multipenyakit penyerta dan harapan hidup yang pendek..$^{17}$

Berdasarkan hasil penelitian menunjukkan bahwa status gizi berdasarkan pola konsumsi makanan informan yaitu dari informan yang memiliki status gizi normal kekurangan asupan gizi mikro vitamin $a$, vitamin $b$ dan vitamin $\mathrm{c}$; dan kekurangan asupan energi, protein dan karbohidrat mengalami defisit ringan; dan asupan lemak defisit berat. Informan dengan status gizi gemuk memiliki asupan energi defisit berat, protein lebih, lemak normal, karbohidrat defisit berat dan asupan vitamin $A, B, C$ dan $Z n$ kurang, tidak sesuainya kecukupan gizi dari informan tersebut karena keputusan menurunkan berat badan. Semua informan melaporkan bahwa mereka menggunakan lemak dan minyak selama persiapan makanan untuk menggoreng makanan mereka. Kelompok makanan yang paling sering dikonsumsi lainnya adalah buah-buahan, kacang-kacangan dan bijibijian melalui pangan lokal tempe dan tahu. Makanan yang paling sedikit dikonsumsi adalah daging. Informan penelitian ini bejenis kelamin perempuan, dimana ODHA perempuan memang memiliki kecenderungan untuk kelebihan berat badan dan obesitas. ${ }^{42,43}$
Kekurangan asupan mikronutrien menyebabkan perkembangan penyakit HIV yang lebih cepat, perubahan fungsi kekebalan tubuh, dan mortalitas. ${ }^{44}$ Vitamin a, vitamin c, vitamin $b$ dan zink merupakan zat gizi mikro ini diperlukan dalam sistem kekebalan tubuh karena dapat berperan sebagai zat gizi antioksidan sehingga akan meningkatkan kualitas hidup. ${ }^{45}$ Keseimbangan protein, karbohidrat dan lemak akan mengurangi risiko kesakitan dan kematian pada ODHA. ${ }^{46}$ Namun kelebihan asupan energi, karbohidrat lemak atau protein akan menyebabkan berat badan lebih atau kegemukan. ${ }^{26}$ Informan dengan status gizi obesitas memiliki asupan energi dan lemak lebih; asupan protein, vitamin $\mathrm{b}$, dan $\mathrm{Zn}$ normal; asupan karbohidrat defisit ringan dan vitamin A kurang, dengan aktivitas fisik ringan. Obesitas pada ODHA memiliki risiko yang sama dengan kekurangan gizi pada ODHA, akan menyebabkan menurunnya kekbalan tubuh dan meningkatkan resiko morbiditas dan timbulnya penyakit penyerta seperti diabetes, dan penyakit kardiovaskuler. $43,47,48$

Pada penelitian ini informan mengatakan keputusan memilih makanan tidak berdasar pada kandungan gizinya walaupun mereka tau salah satu yang meningkatkan kekebalan tubuh adalah makanan yang bernilai gizi. Namun minimnya pengetahuan dan lemahnya perekonomian membuat informan tidak mampu memilih ragam pangan untuk dikonsumsi. Studi sebelumnya menjelaskan ketidakmampuan ODHA memenuhi asupan gizi individu salah satunya dikarena ketidakmampuan secara finansial. ${ }^{49-51}$ ODHA akan memprioritaskan menyiapkan alokasi dana untuk pengobatan mulai dari kebutuhan akses menuju pelayanan kesehatan dan kondisi tidak terduga ketika kondisi tubuh mengalami penurunan dibanding untuk kebutuhan pangan.9,12,13 Penyebab lain kurangnya kecukupan gizi adalah tidak beragamnya pilihan pangan seseorang akibat kurangnya pengetahuan dan informasi mengenai keragaman pangan dan kandungan gizi. ${ }^{52,53}$ Pemilihan pangan yang dipilih oleh informan belum beragam walaupun mendapat bantuan tambahan makanan dari Pemerintah. Hal ini disebabkan karena tidak adanya edukasi gizi dan ahli gizi yang mendampingi selama melakukan terapi ARV sehingga ODHA tidak bisa mengupayakan keragaman makanan yanng murah dan mudah, padahal ODHA 
dianjurkan untuk mengkonsumsi jenis makanan yang beragam. ${ }^{6}$ Informan tidak mendapatkan pantauan dan konseling gizi dari ahli gizi. Konseling gizi dapat membawa perubahan perilaku makan antara lain terjadinya peningkatan/perbaikan pengetahuan, sikap dan praktek ODHA dalam pemilihan bahan makanan dan mengatasi gejala infeksi serta pemenuhan asupan zat gizi yang dibutuhkan guna peningkatan status gizi. ${ }^{54}$

Berbagai studi pun mengungkapkan bahwa pengetahuan gizi akan mempengaruhi keragaman makanan. ${ }^{55,56}$ Seiring meningkatnya pengetahuan gizi individu, variasi makanan yang dikonsumsi juga meningkat sehingga meningkatkan keragaman zat gizi akan diserap dan dengan demikian kecukupan gizi diperoleh. ${ }^{55}$ Informasi gizi harus menjadi komponen kunci dalam perawatan ODHA dan harus dimulai pada awal dimulainya perawatan komprehensif. Pendidikan gizi termasuk tentang makanan murah dan sehat harus dilakukan berkelanjutan sepanjang periode perawatan. Selain pendidikan gizi, perubahan pada tingkat kebijakan mengenai aksesabilitas makanan sehat terbukti meningkatkan keterjangkauan makanan sehat di lingkungan berpenghasilan rendah. ${ }^{56}$

Walaupun penelitian ini telah dilakukan oleh peneliti dan enumerator yang telah dilatih dan sesuai prosedur, namun karena melakukan penggalian informasi lampau maka penelitian ini tidak terhindar dari bias informasi. Bias informasi dapat disebabkan karena kemungkinan lemahnya ingatan informan untuk melaporkan makanan yang dikonsumsi pada hari sebelumnya dan kurangnya kejujuran informan saat dilakukan wawancara mendalam.

\section{SIMPULAN DAN SARAN}

\section{Simpulan}

Status gizi informan adalah kategori normal, gemuk dan obesitas dengan aktivitas fisik ringan dan sedang. Status kecukupan energi yaitu 2 informan defisit berat, 1 informan defisit ringan, 1 informan lebih dan 1 informan normal. Status kecukupan protein yaitu 2 informan defisit berat, 1 informan lebih dan 2 informan normal. Status kecukupan karbohidrat yaitu 2 informan defisit berat dan 3 informan defisit ringan. Semua informan mengalami kekurangan vitamin a, 1 informan memiliki status kecukupan vitamin b dan vitamin $\mathrm{c}$ normal, lainnya mengalami kekurangan. Status kecukupan zink yaitu 2 kurang dan 3 normal. Hambatan pemenuhan zat gizi disebabkan kurangnya pengetahuan kebutuhan gizi, variasi makanan, dan lemahnya ekonomi informan.

\section{Saran}

Pemantauan pada ODHA tidak hanya pada kegiatan pengobatan dan kontrol kesehatan fisik namun diperlukan juga layanan pendampingan, konseling dan edukasi gizi, sehingga perlu adanya tenaga kesehatan gizi yang terlibat dalam pendampingan dan pengobatan HIVIAIDS. Pemerintah perlu tetap mengalokasikan anggaran untuk keperluan penyediaan bantuan makanan tambahan bagi ODHA guna memberikan asupan zat gizi yang beragam. Selain itu, ODHA dapat memilih makanan murah yang beragam dengan kandungan gizi tepat, memperbaiki pola konsumsi, dan mulai meningkatkan aktivitas fisik untuk meningkatkan kekebalan tubuh.

\section{UCAPAN TERIMA KASIH}

Ucapan terima kasih disampaikan pada Lembaga Setulus Kasih dan Komisi Penganggulangan AIDS (KPA) Kota Kediri yang sudah membantu proses penelitian dengan mengarahakan pada informan yang terlibat pada penelitian ini.

\section{RUJUKAN}

1. UNAIDS. 2019-global-AIDS-update. Communities at the Centre. 2019.

2. Kementerian Kesehatan RI. Laporan Perkembangan HIVIAIDS dan PIMS (TRIWULAN IV) TAHUN 2019. Jakarta; 2019.

3. Kediri DKK. Laporan Perkembangan HIVIAIDS. Kota Kediri; 2019.

4. Bain LE, Nkoke C, Noubiap JJN. UNAIDS 90-90-90 targets to end the AIDS epidemic by 2020 are not realistic: Comment on "Can the UNAIDS 90-9090 target be achieved? A systematic analysis of national HIV treatment cascades." BMJ Glob Heal. 2017;2(2):2016-8.

5. WHO. Nutritional Support [Internet]. Nutritional Support. [cited 2020 Jul 1]. Available 
https://www.who.int/hiv/topics/nutritional /support/en/

6. FANTA. HIV / AIDS: A Guide For Nutrition, Care and Support July 2001. Washington DC: Food and Nutrition Technical Assistance Project, Academy fo Ecucational Development; 2001.

7. Hailemariam S, Bune GT, Ayele HT. Malnutrition: Prevalence and its associated factors in People living with HIVIAIDS, in Dilla University Referral Hospital. Arch Public Heal [Internet]. 2013;71(1):1. Available from: Archives of Public Health

8. Byron E, Gillespie S, Nangami M. Integrating nutrition security with treatment of people living with HIV: Lessons from Kenya. Food Nutr Bull. 2008;29(2):87-97.

9. Nakanwagi S, Matovu JKB, Kintu BN, Kaharuza F, Wanyenze RK. Facilitators and Barriers to Linkage to HIV Care among Female Sex Workers Receiving HIV Testing Services at a CommunityBased Organization in Periurban Uganda: A Qualitative Study. 2016;2016.

10. Russell $S$, Martin $F$, Zalwango $F$, Namukwaya $S$, Nalugya $R$, Muhumuza $R$, et al. Finding meaning: HIV selfmanagement and wellbeing among people taking antiretroviral therapy in Uganda. PLoS One. 2016;11(1):1-16.

11. Campbell $C$, Scott $K$, Skovdal $M$, Madanhire C, Nyamukapa C, Gregson $S$. A good patient? How notions of "a good patient" affect patient-nurse relationships and ART adherence in Zimbabwe. BMC Infect Dis [Internet]. 2015;15(1):1-11. Available from: http://dx.doi.org/10.1186/s12879-015$1139-x$

12. Wouters E, De Wet K. Women's experience of HIV as a chronic illness in South Africa: Hard-earned lives, biographical disruption and moral career. Sociol Heal IIIn. 2016;38(4):521-42.

13. Buhikire K, Voss J, Kigozi J, Nyakato P, Ankunda N, Kalebbo B, et al. Reaching the First 90 in Uganda: Predictors of Success in Contacting and Testing the Named Sexual Partners of HIV+ Index
Clients in Kiboga District. AIDS Behav [Internet]. 2018;22(8):2458-67. Available from: https://doi.org/10.1007/s10461-0182137-y

14. Jaggers JR, Hand GA. Health Benefits of Exercise for People Living With HIV: A Review of the Literature. Am J Lifestyle Med. 2014;10(3):184-92.

15. Monesion RR, Pedrol E. Physical Activity Associated with HIV. J AIDS Clin Res. 2012;03(03).

16. Miller T, Somarriba, Neri, Schaefer. The effect of aging, nutrition, and exercise during HIV infection. HIVIAIDS - Res Palliat Care. 2010;191.

17. Biggs C, Spooner E. Obesity and HIV: A compounding problem. South African J Clin Nutr [Internet]. 2018;31(4):78-83. Available from: https://doi.org/10.1080/16070658.2017. 1404299

18. Mashinya F, Alberts M, Colebunders R, Van Geertruyden JP. Weight status and associated factors among HIV infected people on antiretroviral therapy in rural Dikgale, Limpopo, South Africa. African $J$ Prim Heal care Fam Med. 2016;8(1):1-8.

19. Godfrey C, Bremer A, Alba D, Apovian $C$, Koethe JR, Koliwad S, et al. Obesity and Fat Metabolism in Human Immunodeficiency Virus-Infected Individuals: Immunopathogenic Mechanisms and Clinical Implications. J Infect Dis. 2019;220(3):420-31.

20. Crum-Cianflone N, Tejidor R, Medina S, Barahona I, Ganesan A. Obesity among patients with HIV: The latest epidemic. AIDS Patient Care STDS. 2008;22(12):925-30.

21. Yasin NM, Maranty $H$, Ningsih $R$. Analisis respon terapi pasien HIV / AIDS Response to antiretroviral HIV / AIDS patients antiretroviral therapy pada by. 2011;22(3):212-22.

22. Wanke CA, Silva M, Knox TA, Forrester J, Speigelman D, Gorbach SL. Weight Loss and Wasting Remain Common Complications in Individuals Infected with Human Immunodeficiency Virus in the Era of Highly Active Antiretroviral Therapy. Clin Infect Dis. 
2000;31(3):803-6.

23. Lasmadiwati E. Potensi diri dan alam untuk pengobatan HIV / AIDS. Depok: Penebar Swadaya; 2005.

24. Mehta S, Fawzi W. Effects of Vitamins, Including Vitamin A, on HIVIAIDS Patients. Vitam Horm. 2007;75(06):355-83.

25. KEMENKES. Pedoman Pelayanan Gizi Bagi ODHA. Jakarta: Direktorat Bina Gizi Masyarakat Kemenkes Rl; 2010. 21-65 p.

26. Almatsier S. Prinsip Dasar IImu Gizi. Jakarta: Gramedia Pustaka Utama; 2006.

27. Gibson RS. Principles of Nutritional Assessment. 2nd ed. London: Oxford Press; 2005.

28. Watkins DC. Rapid and Rigorous Qualitative Data Analysis: The "RADaR" Technique for Applied Research. Int J Qualiative Methods. 2017;16:1-9.

29. Tiyou A, Belachew T, Alemseged F, Biadgilign $S$. Food insecurity and associated factors among HIV-infected individuals receiving highly active antiretroviral therapy in Jimma zone Southwest Ethiopia. Nutr J. 2012;11:18.

30. Venter E, Gericke G, Bekker P. Nutritional status, quality of life and CD4 cell count of adults living with HIVIAIDS in the Ga-Rankuwa area. South African J Clin Nutr. 2009;22(3).

31. Almeida AMR, Dos Santos ACO. Nutritional Status and CD4 Cell Counts in Patients with HIVIAIDS Receiving Antiretroviral Therapy. Heal HIV Infected People Food, Nutr Lifestyle with Antiretrovir Drugs. 2015;1(November):243-52.

32. Miftahurachman, Wisaksana R. Hubungan antara Indeks Massa Tubuh dan Jumlah CD4 pada Penderita HIV yang Mendapat Pengobatan ARV. Maj Kedokt Bandung. 2015;47(4):237-41.

33. Feldman JG, Burns DN, Gange SJ, Bacchetti P, Cohen M, Anastos K, et al. Serum albumin as a predictor of survival in HIV-infected women in the Women's Interagency HIV Study. Aids. 2000;14(7):863-70.
34. Hoffman R, Black V, Technau K, van der Merwe KJ, Currier J, Coovadia A, et al. Effects of highly active antiretroviral therapy duration and regimen on risk for mother-to-child transmission of HIV in Johannesburg, South Africa. J Acquir Immune Defic Syndr [Internet]. 2010;54(1):35-41. Available from: https://www.ncbi.nlm.nih.gov/pmc/article s/PMC3624763/pdf/nihms412728.pdf

35. Bares SH, Smeaton LM, Xu A, Godfrey C, McComsey GA. HIV-Infected Women Gain More Weight than HIV-Infected Men Following the Initiation of Antiretroviral Therapy. J Women's Heal. 2018;27(9):1162-9.

36. Kazooba P, Kasamba I, Mayanja BN, Lutaakome J, Namakoola I, Salome T, et al. Cardiometabolic risk among HIVpositive Ugandan adults: Prevalence, predictors and effect of long-term antiretroviral therapy. Pan Afr Med J. 2017;27:1-14.

37. Achhra AC, Sabin C, Ryom L, Hatleberg $\mathrm{C}$, Antonella D'Aminio M, De Wit S, et al. Body mass index and the risk of serious non-AIDS events and all-cause mortality in treated HIV-positive individuals: D:A:D Cohort analysis. Vol. 78, Journal of Acquired Immune Deficiency Syndromes. 2018. 579-588 p.

38. Alcorn K. Weight gain on HIV treatment: more common with newer drugs, low CD4 counts [Internet]. aidsmap.com. 2019 [cited 2021 Feb 5]. Available from: https://www.aidsmap.com/news/oct2019/weight-gain-hiv-treatment-morecommon-newer-drugs-low-cd4counts\#: :text=Some researchers have suggested that,hyperglycaemia but found no association.

39. Khatri S, Amatya A, Shrestha B. Nutritional status and the associated factors among people living with HIV: An evidence from cross-sectional survey in hospital based antiretroviral therapy site in Kathmandu, Nepal. BMC Nutr. 2020;6(1):1-13.

40. Welis W, Sazeli RM. Gizi untuk Aktifitas Fisik dan Kebugaran. Padang: Sukabina Press; 2013.

41. Grace JM, Semple SJ, Combrink S. 
Exercise therapy for human immunodeficiency virus/AIDS patients: Guidelines for clinical exercise therapists. J Exerc Sci Fit [Internet]. 2015;13(1):49-56. Available from: http://dx.doi.org/10.1016/j.jesf.2014.10.0 03

42. Sharma A, Bynum SA, Schneider MF, Cox C, Tien PC, Hershow RC, et al. Changes in Body Mass Index Following HAART Initiation among HIV-Infected Women in the Women's Interagency HIV Study. J AIDS Clin Res. 2014;5.

43. Tate $\mathrm{T}$, Willig $\mathrm{AL}$, Willig $\mathrm{JH}$, Raper $\mathrm{JL}$, Moneyham L, Kempf MC, et al. HIV infection and obesity: Where did all the wasting go? Antivir Ther. 2012;17(7):1281-9.

44. Anand D, Puri S. Anthropometric and nutritional profile of people living with HIV and AIDS in India: An assessment. Indian J Community Med. 2014;39(3):161-8.

45. Siswanto, Budisetyawati, Ernawati F. Peran Beberapa Zat Gizi Mikro Dalam Sistem Imunitas. Gizi Indones. 2014;36(1):57-64.

46. Enwereji EE, Ezeama MC, Onyemachi PEN. Basic Principles of Nutrition, HIV and AIDS: Making Improvements in Diet to Enhance Health. In: Dumais $\mathrm{N}$, editor. Nutrition and HIVIAIDS Implication for Treatment, Prevention and Cure [Internet]. Université de Sherbrooke; 2019. Available from: https://www.intechopen.com/books/nutri tion-and-hiv-aids-implication-fortreatment-prevention-and-cure/basicprinciples-of-nutrition-hiv-and-aidsmaking-improvements-in-diet-toenhance-health

47. CDC. HIV Among Youth [Internet]. 2011. Available from: http://www.cdc.gov/hiv/pdf/library_factsh eet_HIV_amongYouth.pdf

48. Thimmapuram R, Lanka S, Esswein A, Dall L. Correlation of Nutrition with Immune Status in Human Immunodeficiency Virus Outpatients. Mo Med [Internet]. 2019;116(4):336-9.
Available from: http://www.ncbi.nlm.nih.gov/pubmed/31 527985\%0Ahttp://www.pubmedcentral.n in.gov/articlerender.fcgi?artid=PMC6699 812

49. Ivers LC, Cullen KA, Freedberg KA, Block S, Coates J, Webb P. HIVIAIDS, Undernutrition, and Food Insecurity. Clin Infect Dis. 2009;49(7):1096-102.

50. Scott K, Campbell C, Madanhire C, Skovdal M, Nyamukapa C, Gregson S. In what ways do communities support optimal antiretroviral treatment in Zimbabwe? Health Promot Int. 2014;29(4):645-54.

51. Russell S, Namukwaya S, Zalwango F, Seeley J. The Framing and Fashioning of Therapeutic Citizenship among People Living with HIV Taking Antiretroviral Therapy in Uganda. Qual Health Res. 2016;26(11):1447-58.

52. Powell B, Bezner Kerr R, Young SL, Johns $T$. The determinants of dietary diversity and nutrition: Ethnonutrition knowledge of local people in the East Usambara Mountains, Tanzania. J Ethnobiol Ethnomed. 2017;13(1):1-12.

53. Moramarco $S$, Amerio G, L CM, Bonvecchio D, Abramo E, Palombi L, et al. Nutritional Counseling Improves Dietary Diversity and Feeding Habits of Zambian Malnourished Children Admitted in Rainbow Nutritional Programs. Biomed Prev. 2017;

54. Razak R. Pengaruh Konseling Gizi Pada Penderita Hiv / Aids Untuk Perubahan Perilaku Makan Dan Status Gizi. Media Gizi Pangan. 2009;VII:41-8.

55. Gaceri Muthamia O. The Effects of Nutritional Knowledge on the Dietary Practices of People Living with HIV in Kayole Division, Nairobi-Kenya. Int J Nutr Food Sci. 2014;3(6):597.

56. Kinabo J, Mnkeni AP, Nyaruhucha CNM, Msuya J, Haug A, Ishengoma J. Feeding frequency and nutrient content of foods commonly consumed in the Iringa and Morogoro regions in Tanzania. Int $\mathrm{J}$ Food Sci Nutr. 2006;57(1-2):9-17. 